\title{
Seed Coating Technologies and Treatments for Onion: Challenges and Progress
}

\author{
Alan G. Taylor ${ }^{1}$ \\ Department of Horticultural Sciences, New York State Agricultural Experiment Station, \\ Cornell University, Geneva, NY 14456 \\ C.J. Eckenrode ${ }^{2}$ and R.W. Straub ${ }^{3}$ \\ Department of Entomology, New York State Agricultural Experiment Station, Cornell University, Geneva, NY 14456
}

Additional index words. cyromazine, film coating, pelleting, seed enhancements, seed testing

\begin{abstract}
Conventional methods to control the onion maggot or onion fly, Delia antiqua (Meigen), have relied on in-furrow applications of the toxicant pesticide, chlorpyrifos. The objective of this research was to develop an onion (Allium cepa L.) seed treatment that utilizes a new chemistry compound that is environmentally safe. Cyromazine is an insect growth regulator with a mode of action different from traditional pesticides used to control onion maggot. Cyromazine has low mammalian toxicity and is relatively nontoxic to other insects, including beneficials. High seed loading rates $\left(50 \mathrm{~g} \cdot \mathrm{kg}^{-1}\right.$ active ingredient) are required for optimal efficacy, and conventional slurry methods are inadequate to apply these high loading rates. Film coating and pelleting were performed at Cornell Univ. to apply cyromazine and a registered fungicide (a formulation of thiram and carboxin) to onion seeds. Results of field studies performed over several years revealed that stand losses due to the onion maggot ranged from $\approx 20 \%$ to $60 \%$. Cyromazine applied by either film coating or pelleting decreased the loss by onion maggot from $1 \%$ to $8 \%$, and efficacy was comparable to an in-furrow application of chlorpyrifos. Cyromazine was registered as a seed treatment and is commercially used in the northeastern and midwestern United States, where onion maggot is a serious pest. Field emergence was not negatively affected by cyromazine coated onto the seeds when onion seeds are sown in organic (muck) soils. There is other evidence, however, that cyromazine seed treatments may cause phytotoxicity to germination and seedling growth. Testing seed quality in sand or on roll towels revealed a high percentage of abnormal seedlings. Retarded root growth was observed in seeds treated with cyromazine, resulting in an increase in abnormal seedling classifications. A finely ground sphagnum peatmoss applied over the seeds in a roll towel test ameliorated the abnormal root growth symptoms, and seedlings had robust growth. Collectively, film coating and pelleting were effective delivery systems for the application of plant protectants required at time of sowing. Modification of the standard germination test was needed to accurately assess onion seed quality. Moreover, this project was successful due to a team effort of a university seed scientist and entomologists working with onion growers and industry. Future registrations on small acreage, high-value horticultural crops are envisioned to require similar multi-partner approaches. Chemical name used: $N$-cyclopropyl-1,3,5-triazine-2,4,6-triamine (cyromazine).
\end{abstract}

The onion maggot, Delia antiqua (Meigen), is a major insect pest of commercial onion (Allium cepa L.) production in northeastern United States, Canada, and other temperate regions of the world (Ellis and Eckenrode, 1979). This insect normally completes multiple generations (Fig. 1) within each season with onions and its relatives as primary hosts (Eckenrode et al., 1975; Ellis and Eckenrode, 1979). Immature stages of the onion maggot dwell within or just outside the underground portions of the plant, and the larval stages attack seedlings and bulbs (Fig. 2). The onion maggot is particularly damaging where the crop is intensively grown on high organic (muck) soils, and stand losses can exceed 50\%. Because

Received for publication 26 July 2000. Accepted for publication 10 Jan. 2001. We thank the following persons for their valuable assistance: D. Paine, M.L. Hessney, D. Webb, H. Grimsland, and E. Chirco. Colorcon, Seed Dynamics, Seminis, Swedesboro, and Coating Supply provided useful suggestions in developing the coating and seed technology aspects of the project. This work was partially supported from grants by the New York Onion Growers Association, Syngenta Crop Protection-Seed treatment group and by other industry funds. The cost of publishing this paper was defrayed in part by the payment of page charges. Under postal regulations, this paper therefore must be hereby marked advertisement solely to indicate this fact.

${ }^{1}$ Professor of Seed Science and Technology. To whom reprint requests should be addressed. E-mail address: agt1@cornell.edu ${ }^{2}$ Emeritus Professor of Entomology.

${ }^{3}$ Professor of Entomology. onion production is specialized and costly, many growers rely primarily on this one crop, resulting in minimal rotations to other plant species. This practice invariably increases onion maggot pressure, thus a system in which onions are grown either continuously or in close proximity to last year's plantings must rely heavily upon effective chemical pesticides applied at seeding to control the larval stages (Eckenrode and Nyrop, 1995).

Insecticide resistance is a major concern in pest management control strategies. Chapman (1960) called attention to resistance to organic insecticides in vegetable crops, including onions, over 40 years ago. The number of labeled soil-applied insecticides for onion maggot control has been barely adequate (Straub and

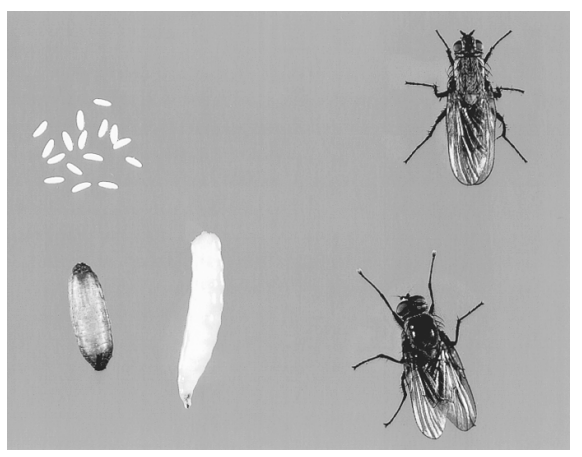

Fig. 1. Life cycle of onion maggot (Delia antiqua Meigen). Clockwise from top right: adult female, adult male, larva, pupa, and eggs.
Davis, 1978), and the primary reason for the loss of efficacy was the onset of insecticide resistance in commercial onion-growing areas. Chlorpyrifos, marketed as Lorsban ${ }^{\circledR}$ (Dow AgroSciences, Indianapolis), has been the most effective and reliable soil insecticide for onion maggot control since it was labeled for that use in the early 1980s. Recently, measurable levels of resistance have been documented in onion maggot populations collected from selected sites in New York, Michigan, and Wisconsin (Eckenrode and Nyrop, 1995). Although efficacy is declining, chlorpyrifos still provides effective control in many areas when applied with precision at maximum-labeled rates. There is a need for new unrelated chemical treatments to minimize the probability for cross-resistance to other organo-phosphate soil insecticides. Moreover, there is an increasing

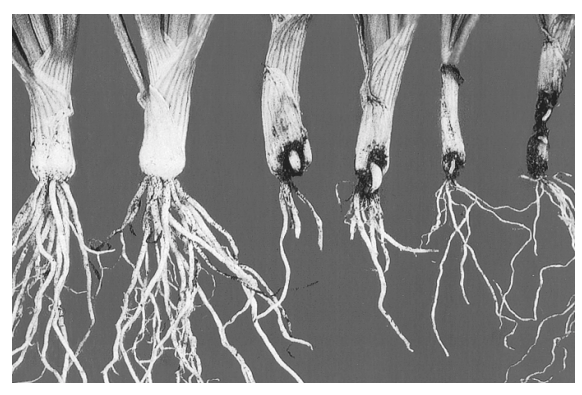

Fig. 2. Damage to onion seedlings (right) caused by onion maggot larvae. 
need for effective methods that use reduced rates of selective insecticides, so populations of ground-dwelling arthropods that are natural enemies of the onion maggot can increase.

Cyromazine is an insect growth regulator, with a mode of action different from traditional pesticides used to control onion maggot. Cyromazine stiffens the larval cuticle (Kotze and Reynolds, 1991), thereby disrupting the morphogenetic processes during juvenile stages of onion maggot and other Diptera species. Cyromazine has low toxicity to mammals (rats): oral $\mathrm{LD}_{50} 3387 \mathrm{mg} \cdot \mathrm{kg}^{-1}$ and dermal $>3100 \mathrm{mg} \cdot \mathrm{kg}^{-1}$ (Farm Chemicals Handbook, 2000). Moreover, cyromazine is relatively nontoxic to other insects, including beneficials. The $\mathrm{LC}_{50 \mathrm{~s}}$ in soil for cyromazine and chlorpyrifos on onion maggot were 17.5 and $8.4 \mathrm{mg} \cdot \mathrm{L}^{-1}$, respectively (Hayden and Grafius, 1990). Cyromazine is systemic, exhibits acropetal movement in plants, and is strongly adsorbed by organic soils (Syngenta Crop Protection). Cyromazine is marketed as Trigard $^{\circledR}$ in the United States and as Governor ${ }^{\circledR}$ in Canada, and is manufactured by Syngenta Crop Protection (Greensboro, N.C.). Both Trigard and Governor ${ }^{\circledR}$ are formulated as wettable powders containing $75 \%$ active ingredient (Farm Chemicals Handbook, 2000).

Traditionally, insecticides have been placed or directed within the furrow as seeds are sown. Seed treatments offer an attractive alternative to in-furrow treatments by delivering lower rates of pesticides directly to the target area. Historically, seed treatments have demonstrated effective control of onion maggot (Rawlins et al., 1960) and the related seed corn maggot, Delia platura (Meigen) (Eckenrode et al., 1973; Howe et al., 1952). Seed treatments also have been used successfully for control of the soilborne disease, onion smut, caused by Urocystis cepulae Frost. PRO$\mathrm{GRO}^{\circledR}$, a mixture of $50 \%$ active ingredient thiram and $30 \%$ active ingredient carboxin (Gustafson, Dallas) is currently labeled with a Section 18 for use on onion seeds (California Environmental Protection Agency, 2000). PRO-GRO ${ }^{\circledR}$ was used as a standard seed treatment for control of onion smut in our studies.

Seed treatments refer to chemicals or agents that are applied to seeds. However, specific coating technologies are needed to effectively apply the seed treatments uniformly over the seed surface and uniformly from seed-to-seed. Pelleting and film coating are two methods for which working definitions have been developed in the seed industry for several coating technologies (Butler, 1993). Pelleting is defined as the deposition of a layer of inert materials that may obscure the original shape and size of the seed, resulting in a substantial weight increase and improved plantability. Film coating retains the shape and the general size of the raw seed with minimal weight gain. The coating should result in a more or less continuous coating, which eliminates or minimizes product dust-off. Low product dust-off is an important factor in worker safety.

Seed pelleting consists of the application of solid particles that act as a filler or bulking agent with a binder or adhesive to form a more or less spherically shaped dispersal unit. The pelleting process is commonly performed in a coating pan or tumbling drum. Binders can be mixed with water and sprayed onto the seeds, or blended dry with the filler. Commercial coating formulations usually are blends of binders and fillers, formulated as dry powders (Halmer, 2000). In an alternating manner, powder is dusted and water sprayed onto seeds during the coating operation. Water temporarily binds the pellet and activates the adhesive. Pelleting is a wet operation and therefore pellets must be dried at the completion of the coating process. Pellet build-up is the ratio of filler material to seed, expressed on a weight basis. The build-up for onion varied with commercial pellet manufacturer and ranged from 4:1 to 9:1 (Taylor et al., 1997).

Film coating of seeds is a more recent development. Materials and procedures for film coating were originally developed for the pharmaceutical and confectionery industries. Film coating consists of spraying a solution or suspension of film-forming polymer onto seeds to achieve a uniform deposition of materials. Coating pans used for pelleting may also be used; however, in contrast to the wet operation of pelleting, the aqueous film-forming formulation must be dried immediately after spraying to avoid agglomeration. The percentage of weight increase is about two orders of magnitude less for film coating than for pelleting (Fig. 3). The percentage of weight increase generally ranges from $2 \%$ to $5 \%$ of the seed weight. The reader is referred to several reviews on the materials and equipment for film coating and pelleting (Halmer, 2000; Hill, 1999; Robani, 1994; Taylor et al., 1998).

Both pelleting and film coating can serve as a delivery system for plant protectants required at high-loading rates. In the case of pelleting, the active ingredients, formulated as dry powders, can be applied in the outer pellet layers. Final coating applications with filler material encapsulate the plant protectants and prevent worker exposure to the active ingredients. This application, termed pellet loading
(Hill, 1999), avoids direct contact of the plant protectants with the seed surface. This physical separation reduces phytotoxicity caused by high concentrations of particular plant protectants. In the case of film coating, using high loading rates of plant protectants can contribute significantly to the percentage of weight increase and build-up of the film coating. However, a spatial separation between the plant protectants and seed surface is not obtained as described for pellet loading.

Seed testing is essential to ensure that only high-quality lots are used in production agriculture. The standard germination test is used to assess seed quality and is conducted under ideal laboratory conditions (Association of Official Seed Analysts, 1993). The criteria for germination used by physiologists is radicle emergence; however, seed analysts extend this interpretation by classification of seedlings as either normal or abnormal. Abnormal seedlings are those seedlings with a compromised root and/or shoot development or other seedling defects (Association of Official Seed Analysts, 1992). Only the percentage of normal seedlings is reported for germination of a lot, and is determined after a specified time to allow for complete germination. Other seed quality or vigor tests may be used for onions; however, the standard germination test is the only test accepted for commercial labeling.

Seed quality is affected by many factors, and onion seeds are naturally short-lived in comparison with other vegetable seeds (Taylor, 1997). Seed quality can decline rapidly, especially if seeds are stored in warm, humid conditions. Commercial seed technology practices or treatments may also affect seed quality. The seed pellet or film coating may act as a barrier to gas diffusion (Duran and Burris, 1997). The coating may thus retard the germination rate and reduce the percentage of germination in comparison with the raw or noncoated seeds. Chemical seed treatments may have a detrimental affect on seed germination under laboratory conditions.

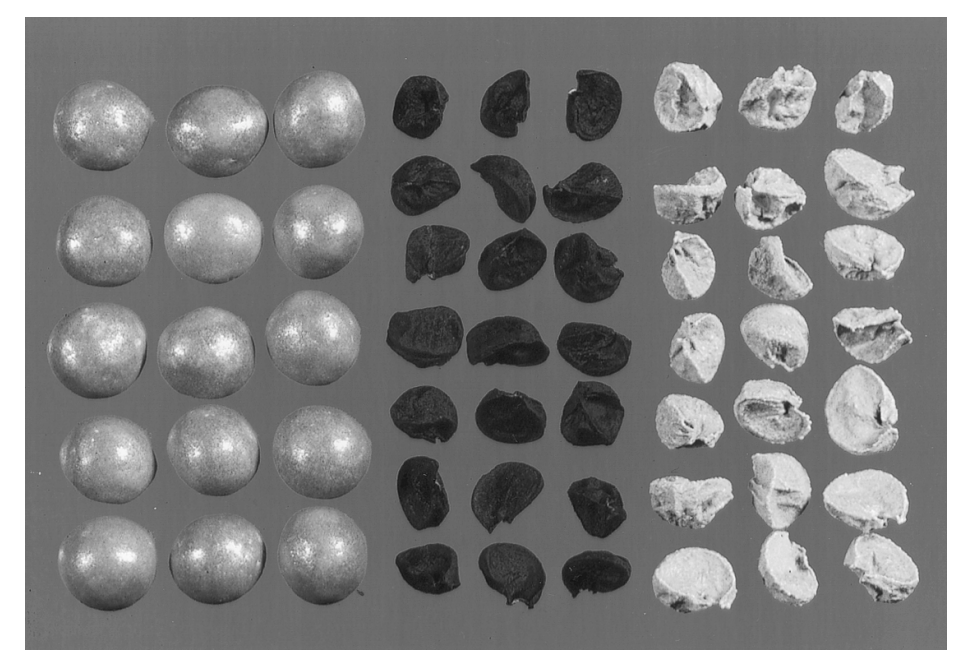

Fig. 3. Pelleted, nontreated (raw), and film-coated onion seeds. 
Phytotoxicity is commonly expressed as stunted root growth and retarded development. The particular seed testing method may produce artifacts in measuring the true germination of a particular lot. Therefore, seed testing methods are needed to accurately assess seed quality of commercial lots.

This paper describes university research efforts in the development and evolution of seed treatment and germination testing protocols for commercial onion production. The transition from traditional in-furrow applications to effective seed treatments is presented. The role of Cornell University's research team working with industry is illustrated, along with the collaborative role of Cornell with other university pest management specialists. The challenges and progress of developing appropriate seed testing methods are highlighted. The overall success of the project was forged by the cooperation of seed technologists working with field entomologists.

\section{IN-FURROW STUDIES}

Cyromazine, formulated as Trigard ${ }^{\circledR} 75 \%$ WP, was first studied as an in-furrow treatment for control of onion maggot. A dosage study was conducted in Potter, N.Y., in 1989, with Trigard ${ }^{\circledR}$ applied as an in-furrow drench at time of sowing. Insect damage was high, with a $60 \%$ reduction in stand in the nontreated check (Fig. 4). An exponential decrease in onion maggot loss was measured with an increase in Trigard $^{\circledR}$ application rate $\left(R^{2}=\right.$ $\left.0.973^{* *}\right)$. An application rate of $0.84 \mathrm{~kg} \cdot \mathrm{ha}^{-1}$ active ingredient was considered to provide acceptable control. Similar levels of onion maggot control were obtained by application of Trigard ${ }^{\circledR}$ formulated as a granule or drench applied in-furrow, while band applications were less effective (Grafius and Hayden, 1988). Efficacy of Trigard ${ }^{\circledR}$ applied in-furrow was further supported in 1990 field studies in New York (Robbins et al., 1991).

\section{SEED COATING INVESTIGATIONS}

Research was initiated in 1990 to develop seed-coating technologies for Trigard ${ }^{\circledR}$ application on onion seeds. Facilities were developed in the Dept. of Horticultural Sciences for performing these coating techniques in the senior author's laboratory. The application of Trigard ${ }^{\circledR}$ was tested at 25 to $100 \mathrm{~g} \cdot \mathrm{kg}^{-1}$ active ingredient, and PRO-GRO ${ }^{\circledR}$, the labeled seed treatment fungicide, was co-applied at 20 $\mathrm{g} \cdot \mathrm{kg}^{-1}$ active ingredient. Conventional slurry application techniques were not able to apply these high loading rates of plant protectants. Thus Trigard ${ }^{\circledR}$ and PRO-GRO ${ }^{\circledR}$ were applied by pelleting or film coating in a laboratoryscale, $40-\mathrm{cm}$ coating pan. Seeds were pelleted using 140 mesh $(105 \mu \mathrm{m})$ quartz sand for the filler and polyvinyl alcohol (PVA) (Airvol 203; Air Products and Chemicals, Allentown, $\mathrm{Pa}$.) for the binder. The PVA was prepared as a $10 \%$ solution and sprayed onto the seeds with a hobby airbrush (Badger AirBrush, Franklin Park, Ill.). Plant protectants in dry powder form were mixed with sand and incorporated into the outer layer of the pellet. Preliminary studies were reported on efficacy of Trigard ${ }^{\circledR}$ in our sand pellet, and carry-over studies from 1990 to 1991 (Webb et al., 1992).

Seeds were also film-coated with a commercial film-forming formulation, Opadry $\mathrm{F}$ (Colorcon, West Point, Pa.). The dry filmforming powder was mixed with water and sprayed onto the seeds with a professional automatic spray gun (Binks model 460; Franklin Park, Ill.) in the coating pan. The coating pan was ventilated by passing warm air into the opening of the pan during the coating operation. Trigard $^{\circledR}$, formulated as a $75 \%$ wettable powder, was mixed with the film-forming polymer. $\mathrm{PRO}-G R O^{\circledR}$, formulated as a dust by Gustafson, was sifted onto the seeds during the coating process in the coating pan.

Field studies were performed to test efficacy of Trigard ${ }^{\circledR}$ applied by pelleting or film coating in Prattsburg, N.Y., in 1992. The percentage of loss to onion maggot exceeded $40 \%$ for the nontreated (raw) seeds (Fig. 5). The pellet alone or pellet with fungicide did not affect onion maggot damage. Trigard ${ }^{\circledR}$ applied in the pellet to provide from 25 to $100 \mathrm{~g} \cdot \mathrm{kg}^{-1}$ active ingredient significantly reduced onion maggot damage, and results were comparable to the in-furrow check of chlorpyrifos. In the film-coating study, losses due to onion maggot approached $60 \%$ for the raw seed, while the percentage of loss was $<5 \%$ for Trigard ${ }^{\circledR}$ or the in-furrow treatment (Fig. 6). Based on these results and other studies, the recommended rate of Trigard ${ }^{\circledR}$ applied in either a pellet or film coating is $50 \mathrm{~g} \cdot \mathrm{kg}^{-1}$ active ingredient.

Seed coating research continued with the use of new pelleting and film coating materials. Another pellet formulation was tested and consisted of diatomaceous earth (DE) (K108; Celite Corp., Lompoc, Calif.) as the filler, and a finely ground polyvinyl alcohol (Airvol 205S; Air Products and Chemicals, Allentown, Pa.). The DE and

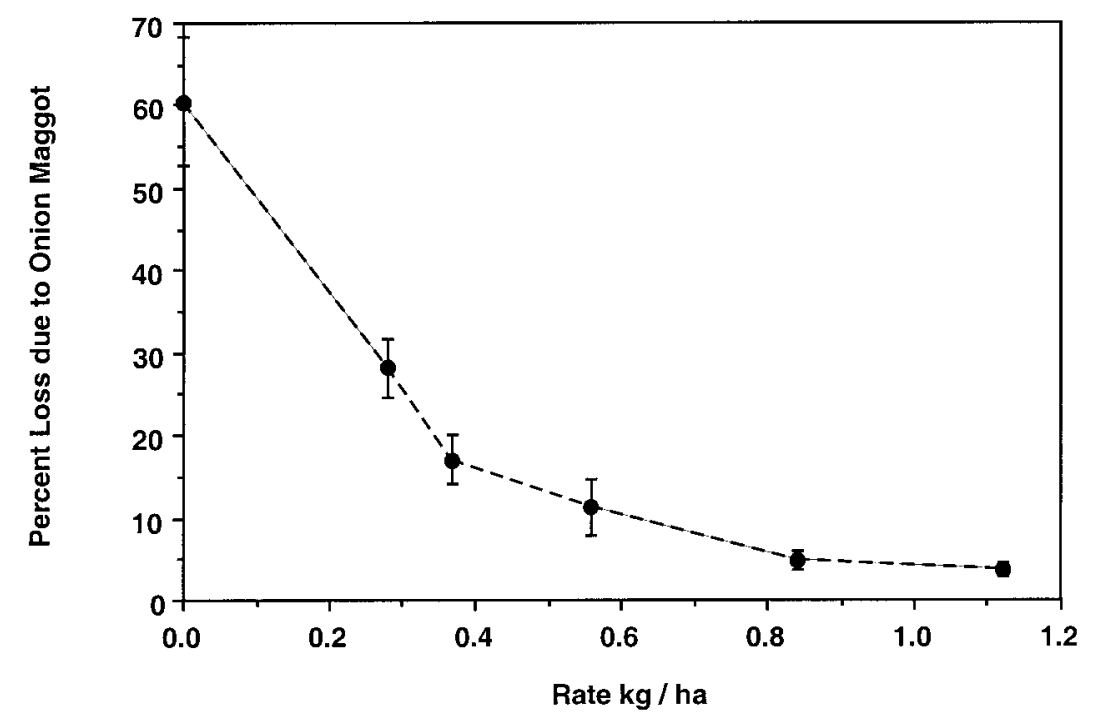

Fig. 4. The effect of in-furrow application rate of Trigard $^{\circledR}$ on percentage of loss due to onion maggot.

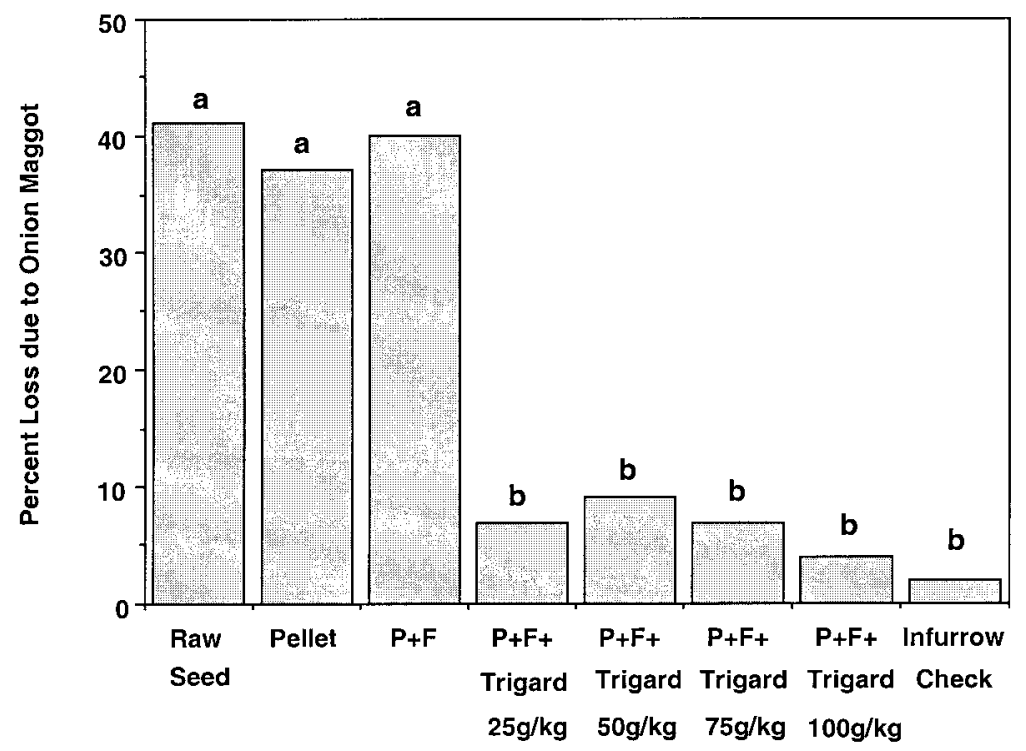

Fig. 5. Trigard ${ }^{\circledR}$ applied in a seed pellet on the percentage of loss due to onion maggot. Selected treatments were pelleted $(\mathrm{P})$ or received the fungicide (F) PRO-GRO ${ }^{\circledR}$. In-furrow check was chlorpyrifos, as Lorsban ${ }^{\circledR}$. 
PVA were mixed and applied as a dry blend. Water was sprayed onto the seeds to activate the binder to adhere the pelleting materials to the seeds. Colorcon developed a film-coating formulation for commercial seed coating called Opadry AG, which replaced the Opadry F. Trigard $^{\circledR}$ and PRO-GRO ${ }^{\circledR}$ were applied as previously described.

Field studies were performed in Prattsburg and Pine Island, N.Y., in 1993. Stand counts were recorded as the number of seedlings per $6 \mathrm{~m}$ of row. In general, the older sand pellet had the lowest stand at both locations (Table 1). Similar seedling emergence was obtained from the DE pellet and film-coated treatments at both locations. In general, onion maggot pressure was higher in Prattsburg ( $\geq 32 \%$ loss) than Pine Island ( $\geq 15 \%$ loss) for treatments without Trigard ${ }^{\circledR}$ or the in-furrow treatment. Trigard $^{\circledR}$, applied in either pellet or film coat, provided good control of onion maggots, and was comparable to the in-furrow application of Lorsban ${ }^{\circledR}$.

Expanded studies were conducted on the seeds treated at Cornell by other university entomologists in 1992 and 1993. Collaborative studies were performed by G. Ritcey and M.R. McDonald at the Univ. of Guelph, and E. Grafius and M. Davis at Michigan State Univ. Onion maggot injury was significantly reduced by Trigard ${ }^{\circledR}$ applied in the sand or DE pellet and film-coated seeds in field studies in Michigan in 1993 (Davis et al., 1994).

\section{COMMERCIAL PELLET TRIALS}

Based on positive research results from Cornell and other university programs, Trigard $^{\circledR}$ was to be tested in commercial pelleting formulations. The former CibaGeigy Corp. (then named Novartis Crop Protection, and most recently Syngenta Crop Protection) in consultation with university faculty, coordinated studies with four pelleting companies: Incotec and Asgrow (now Seminis, Salinas, Calif.), Seed Dynamics (Salinas, Calif.), and Seed Systems (Gilroy, Calif.). Seed companies, randomly termed A, $\mathrm{B}, \mathrm{C}$, and D, were tested blind. Seeds of the same cultivar and seed lot were sent to the four companies, and each company coated samples with their own proprietary pelleting. The field treatments were: 1) seeds pelleted with PRO-GRO ${ }^{\circledR}$ only; 2) seeds pelleted with PRO-GRO $^{\circledR}+$ Trigard $^{\circledR}$; and 3 ) seeds pelleted with PRO-GRO ${ }^{\circledR}$ and an in-furrow application of Lorsban ${ }^{\circledR}$.

Field studies were performed in two locations in Prattsburg, N.Y., (site 1) and Oswego, N.Y., (site 2) in 1994. Percentage of seedling loss due to onion maggot was analyzed as a factorial arrangement of treatments (three seed

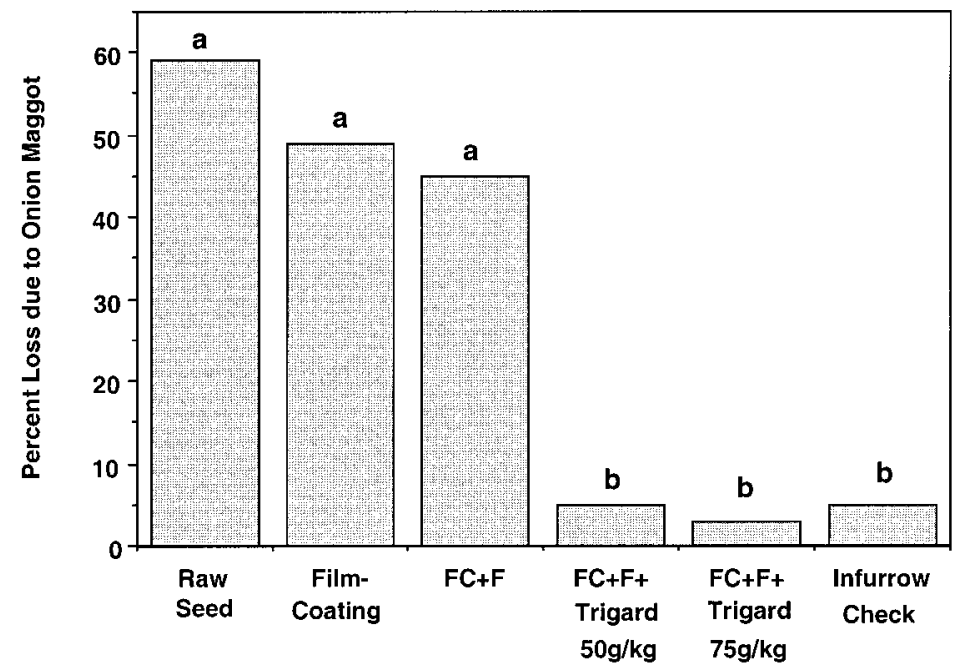

Fig. 6. Trigard ${ }^{\circledR}$ applied in a film coating on the percentage of loss due to onion maggot. Selected treatments were film-coated (FC) or received the fungicide (F) PRO-GRO ${ }^{\circledR}$. In-furrow check was chlorpyrifos, as Lorsban $^{\circledR}$.

Table 1. Seedling establishment, expressed as seedlings per $6 \mathrm{~m}$ of row, and percentage of onion maggot (OM) damage to pelleted and film-coated onion seeds, with or without Trigard $^{\circledR}$ in the coating in comparison with noncoated seeds with in-furrow treatments at two New York locations. In-furrow check was chlorpyrifos, as Lorsban ${ }^{\circledR}$.

\begin{tabular}{|c|c|c|c|c|c|}
\hline \multirow[b]{2}{*}{ Coating } & \multirow[b]{2}{*}{ Treatment } & \multicolumn{2}{|c|}{ Prattsburg } & \multicolumn{2}{|c|}{ Pine Island } \\
\hline & & $\begin{array}{c}\text { Seedlings } \\
\text { per } 6 \mathrm{~m} \text { (no.) }\end{array}$ & $\begin{array}{c}\text { OM damage } \\
(\%)\end{array}$ & $\begin{array}{l}\text { Seedlings } \\
\text { per } 6 \mathrm{~m} \text { (no.) }\end{array}$ & $\begin{array}{c}\text { OM damage } \\
(\%)\end{array}$ \\
\hline Pellet-sand & PRO-GRO $^{\circledR}(\mathrm{PG})$ & $62 \mathrm{c}^{\mathrm{z}}$ & $32 \mathrm{a}$ & $37 \mathrm{c}$ & $21 \mathrm{a}$ \\
\hline Pellet-DE & PG & $94 \mathrm{~b}$ & $34 \mathrm{a}$ & $82 \mathrm{ab}$ & $15 \mathrm{a}$ \\
\hline Film-coat & PG & $89 \mathrm{bc}$ & $33 \mathrm{a}$ & $76 \mathrm{~b}$ & $15 \mathrm{a}$ \\
\hline Pellet-sand & PG + Trigard $^{\circledR}(\mathrm{T})$ & $90 \mathrm{~b}$ & $6 \mathrm{~b}$ & $97 \mathrm{ab}$ & $3 \mathrm{~b}$ \\
\hline Pellet-DE & $P G+T$ & $98 \mathrm{~b}$ & $7 \mathrm{~b}$ & $102 \mathrm{ab}$ & $3 \mathrm{~b}$ \\
\hline Film-coat & $P G+T$ & $104 \mathrm{~b}$ & $3 \mathrm{~b}$ & $116 \mathrm{a}$ & $1 \mathrm{~b}$ \\
\hline Noncoated & In-furrow & $140 \mathrm{a}$ & $7 \mathrm{~b}$ & $97 \mathrm{ab}$ & $5 \mathrm{~b}$ \\
\hline
\end{tabular}

${ }^{2}$ Mean separation within columns by LSD $(P \leq 0.05)$. treatments $\times$ four companies). Overall, insect pressure was greater at site 1 ; however, the trends from both sites were similar (Table 2). The main effect of seed treatment was significant at each site, and Trigard $^{\circledR}$ in the pellet provided the best control. The in-furrow treatment was intermediate in response at site 2 . Lorsban ${ }^{\circledR}$ resistance had been documented from this site (Eckenrode and Nyrop, 1995), and data from this study further supported the decreased efficacy of Lorsban ${ }^{\circledR}$. No differences were measured in onion maggot control due to pelleting source. Parallel studies were performed in Michigan in 1994 with the same commercially pelleted seeds. A hot and dry growing season reduced stands and little onion maggot damage was recorded; however, early stand counts were greater from pelleted treatments with Trigard $^{\circledR}$ than with PRO-GRO ${ }^{\circledR}$ only (Davis et al., 1995).

Seed coating and field research continued over the next 5 years on Trigard ${ }^{\circledR}$ applied as either a film coat or pellet. One modification was the application of PRO-GRO ${ }^{\circledR}$ in the film-coating suspension, rather than being applied as a dust during the coating operation. The sequence of preparing coating mixture was important; the film-forming polymer was first mixed thoroughly with water, and then the plant protectants added. In field studies, Trigard ${ }^{\circledR}$ was consistent in providing good control of onion maggot (Webb et al., 1996). The Trigard ${ }^{\circledR}$ seed treatment became the standard with which to compare other new chemistry seed treatments (Eckenrode et al., 1999).

\section{SEED QUALITY TESTING}

An essential component of seed technology is seed testing to ensure the quality of the seeds being sown. Seed lots that are either film-coated or pelleted with PRO-GRO ${ }^{\circledR}+$ Trigard $^{\circledR}$ are tested in a seed testing laboratory. The coating with plant protectants may be detrimental to the germination and/or seedling growth of the onions. A germination test was performed in sand using film-coated seeds described earlier. The nontreated (raw) seeds and film-coated seeds without plant protectants resulted in $\geq 95 \%$ normal seedlings (Fig. 7). The addition of PRO-GRO ${ }^{\circledR}$ to the film coating resulted in $91 \%$ normal and $7 \%$ abnormal seedlings, while the combination of Trigard ${ }^{\circledR}$ + PRO-GRO ${ }^{\circledR}$ had $>30 \%$ abnormal seedlings. Impaired or severely retarded root growth resulted in abnormal seedling classifications. These root growth abnormalities were observed in both film-coated and pelleted seeds that were treated with Trigard ${ }^{\circledR}$.

Seedling growth and development appeared normal in the field where onions were grown in a high organic matter (muck) soil. Therefore, it seems that the organic matter in the muck soil might adsorb or detoxify the chemical plant protectants. Research was performed to modify the testing media, within the interpretation of the Rules of Testing Seeds (Association of Official Seed Analysts, 1993). Three commercial varieties were pelleted by Incotec, and each variety was treated with thiram, 
Table 2. Onion maggot damage to commercially pelleted onion seeds with or without Trigard ${ }^{\circledR}$ in the coating in comparison with pelleted seeds with an in-furrow treatment insecticide at two locations in upstate New York. In-furrow check was chlorpyrifos, as Lorsban ${ }^{\circledR}$

\begin{tabular}{|c|c|c|c|}
\hline \multirow[b]{2}{*}{ Treatment } & \multirow[b]{2}{*}{ Company } & \multicolumn{2}{|c|}{ Loss due to onion maggot (\%) } \\
\hline & & Site 1 & Site 2 \\
\hline \multirow[t]{4}{*}{$\overline{\mathrm{PRO}^{-G R O}{ }^{\circledR}(\mathrm{PG})}$} & A & 58 & 21 \\
\hline & B & 57 & 22 \\
\hline & $\mathrm{C}$ & 48 & 21 \\
\hline & $\mathrm{D}$ & 53 & 31 \\
\hline \multirow[t]{4}{*}{ PG + Trigard ${ }^{\circledR}(\mathrm{T})$} & $\mathrm{A}$ & 7 & 2 \\
\hline & B & 8 & 2 \\
\hline & $\mathrm{C}$ & 9 & 4 \\
\hline & $\mathrm{D}$ & 10 & 2 \\
\hline \multirow[t]{4}{*}{ PG + In-furrow } & A & 11 & 22 \\
\hline & B & 7 & 14 \\
\hline & $\mathrm{C}$ & 11 & 11 \\
\hline & $\mathrm{D}$ & 8 & 20 \\
\hline \multicolumn{4}{|c|}{ Main effects } \\
\hline PG & & $54 a^{2}$ & $24 \mathrm{a}$ \\
\hline $\mathrm{PG}+\mathrm{T}$ & & $8 \mathrm{~b}$ & $2 \mathrm{c}$ \\
\hline PG + In-furrow & & $9 \mathrm{~b}$ & $17 \mathrm{~b}$ \\
\hline \multicolumn{4}{|c|}{ Main effects } \\
\hline & Company A & $25 \mathrm{a}^{\mathrm{z}}$ & $15 \mathrm{a}$ \\
\hline & Company B & $24 \mathrm{a}$ & $13 \mathrm{a}$ \\
\hline & Company $\mathrm{C}$ & $23 a$ & $12 \mathrm{a}$ \\
\hline & Company D & $24 \mathrm{a}$ & $18 \mathrm{a}$ \\
\hline
\end{tabular}

${ }^{2}$ Mean separation of main effects by $\operatorname{LSD}(P \leq 0.05)$.

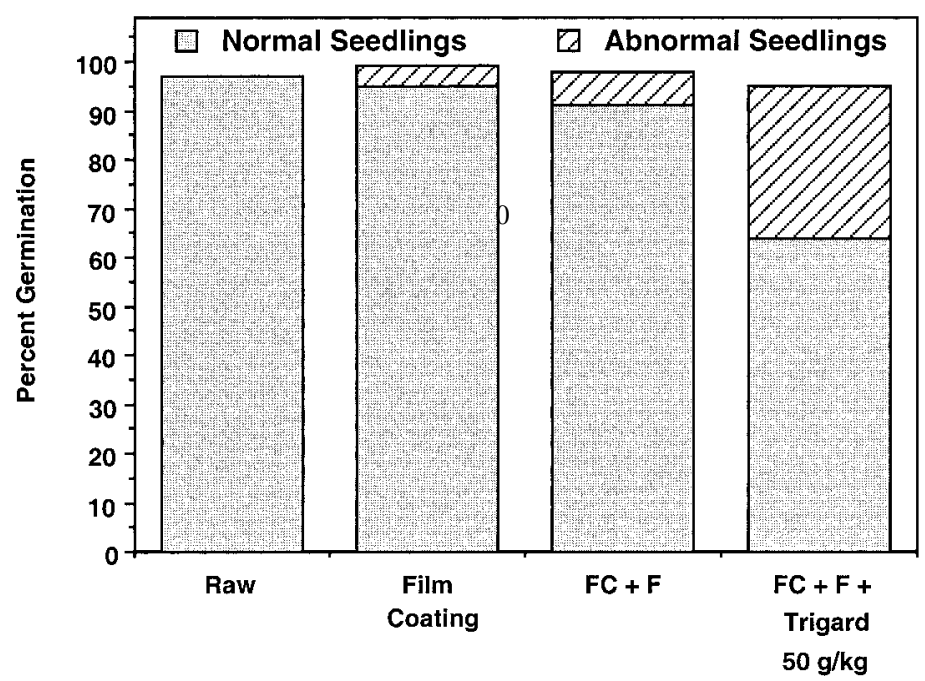

Fig. 7. The percentage of normal and abnormal seedlings of selected seed treatments in a sand germination test. Selected treatments were film-coated (FC) or received the fungicide (F) PRO-GRO ${ }^{\circledR}$

PRO-GRO $^{\circledR}$, or PRO-GRO ${ }^{\circledR}+$ Trigard $^{\circledR}$. The thiram-only treatment served as a check, as this plant protectant was added for control of damping-off organisms (Farm Chemicals Handbook, 2000). Samples were tested in a roll towel test, sand test or roll towel in which the pellets were covered by a peat-lite artificial media (Cornell mix).

The results were consistent for each variety tested, and are summarized in Table 3. A reduction in germination (normal seedlings) was most consistently observed from PRO$\mathrm{GRO}^{\circledR}+$ Trigard $^{\circledR}$ in the roll towel test compared to the thiram-treated seeds. No differences were measured between thiram- and PRO-GRO ${ }^{\circledR}$-treated seeds in the sand test. Therefore, the sand test was suitable for seeds treated with PRO-GRO ${ }^{\circledR}$ only. However, the
PRO-GRO $^{\circledR}+$ Trigard $^{\circledR}$ drastically reduced germination in the sand test. PRO-GRO ${ }^{\circledR}+$ Trigard $^{\circledR}$-treated seed had the highest germination in the peat media in comparison with other test media. Other studies revealed that the Trigard $^{\circledR}$ caused the high percentage of abnormal seedlings and not a synergistic effect between the PRO-GRO ${ }^{\circledR}+$ Trigard $^{\circledR}$. A finely ground sphagnum peatmoss (Scotts, Marysville, Ohio), or pot ground peat, a mixture of blonde and black peat from Europe (supplied by Coating Supply, Palm City, Fla.), were well-suited peat media. Seedling growth was robust in the peat, and onion seedlings had well-developed roots (Fig. 8). A preliminary test should be conducted on nontreated seeds, as some peat batches may be detrimental to germination.

\section{DISCUSSION}

Plant protectants can be applied to seeds by conventional treatments, film coating, encrusting or pelleting. Encrusting has been regarded as making a "mini" pellet (Halmer, 2000), and this product is similar in appearance to filmcoated seed. Low application rates (generally $\leq 2.5 \mathrm{~g} \cdot \mathrm{kg}^{-1}$ ) can be applied as a slurry with conventional coating equipment (Jeffs and Tuppen, 1986). Many current seed treatments and new chemistry materials can be efficacious at low application rates; however, onion maggot treatments require high loading rates. High loading rates are needed both because onion maggot is difficult to control and the plant is vulnerable to infestation from time of sowing through bulbing. Film coating, encrusting, or pelleting is needed to deliver the ${\text { combination of } \text { Trigard }^{\circledR}+\text { PRO-GRO }}^{\circledR}(70$ $\mathrm{g} \cdot \mathrm{kg}^{-1}$ active ingredients or $91.7 \mathrm{~g} \cdot \mathrm{kg}^{-1}$ of formulated materials). Pellet loading (Hill, 1999) has been used to apply dry formulations in a layer during the coating process, thus materials do not have to be hydrated for application. Colorants may be applied as a final step after pelleting to encapsulate the pellet and enhance appearance (Fig. 3). Film coating provides a coating that reduces dust-off, a common problem with seed treatments, and thereby minimizes worker exposure to pesticides. Application uniformity was improved with film-coated in comparison with slurry-treated seeds (Halmer, 1988). Film coating has great potential for uniform application of low and high loading rates in a wide range of horticultural crop seeds.

Film coating or pelleting has been used to apply high loading rates of plant protectants on other crops. Similar to our research with cyromazine, film coating was used in the control of onion maggot (onion fly) in Holland. Leek (Allium porrum L.) seeds rather than onion seeds were investigated with different seed treatment chemistries (Ester and De Vogel, 1994). Control of cabbage root fly (Delia radicum B.), a relative of the onion maggot, was examined on brussels sprouts (Brassica oleracea L. var. gemmifera Schulz) by film coating with chlorpyrifos (Ester et al., 1997). Commercially, selected fungicides and insecticides are applied at high loading rates by coating technologies (Gustafson, 2000). Imidacloprid, marketed as Gaucho ${ }^{\circledR}$, was applied to sugar beet (Beta vulgaris L.) by either film coating or pelleting. Imidacloprid, marketed as Prescribe ${ }^{\circledR}$, was applied to corn (Zea mays L.) at $1.34 \mathrm{mg} / \mathrm{seed}$ active ingredient using seed treatment equipment designed for high application rates (Gustafson, 2001).

In contrast to in-furrow treatments, seed treatments provide a convenient and precise method to apply plant protectants directly into the target area. Effective control of onion maggot with cyromazine required $840 \mathrm{~g} \cdot \mathrm{ha}^{-1}$ as an in-furrow application (Fig. 4) compared with $50 \mathrm{~g} \cdot \mathrm{kg}^{-1}$ active ingredient as a seed treatment (Tables 1 and 2). Seed treatments resulted in an $85 \%$ reduction in pesticide application per unit land area based on commercial practices and planting density. The use of 
Table 3. Laboratory germination tests on commercially pelleted onion seeds treated with thiram, PRO-GRO ${ }^{\circledR}$, or PRO-GRO ${ }^{\circledR}+$ Trigard $^{\circledR}$ performed in sand, roll towel, or roll towel with peat-media.

\begin{tabular}{|c|c|c|c|c|}
\hline \multirow[b]{2}{*}{ Cultivar } & \multirow[b]{2}{*}{ Treatment } & \multicolumn{3}{|c|}{ Germination $(\%)$} \\
\hline & & Sand test & Roll towel & Peat-media towel \\
\hline \multirow[t]{3}{*}{ New York Early } & Thiram & $73 \mathrm{a}^{\mathrm{z}}$ & $73 \mathrm{a}$ & $76 \mathrm{a}$ \\
\hline & PRO-GRO ${ }^{\circledR}$ (PG) & $74 \mathrm{a}$ & $64 \mathrm{bc}$ & $72 \mathrm{a}$ \\
\hline & PG + Trigard $^{\circledR}(\mathrm{T})$ & $49 \mathrm{c}$ & $58 \mathrm{c}$ & $69 \mathrm{ab}$ \\
\hline \multirow[t]{3}{*}{ Criterion } & Thiram & $90 \mathrm{a}$ & $85 \mathrm{abc}$ & $86 \mathrm{abc}$ \\
\hline & PG & $89 a b$ & $80 \mathrm{c}$ & $83 \mathrm{bc}$ \\
\hline & $P G+T$ & $71 \mathrm{~d}$ & $70 \mathrm{~d}$ & $79 \mathrm{c}$ \\
\hline \multirow[t]{3}{*}{ Duration } & Thiram & $88 \mathrm{a}$ & $85 \mathrm{a}$ & 89 a \\
\hline & PG & $87 \mathrm{a}$ & $75 \mathrm{~b}$ & $85 \mathrm{a}$ \\
\hline & $P G+T$ & $57 \mathrm{c}$ & $58 \mathrm{c}$ & $69 \mathrm{~b}$ \\
\hline
\end{tabular}

${ }^{\mathrm{z}}$ Mean separation within varieties by LSD $(P \leq 0.05)$.

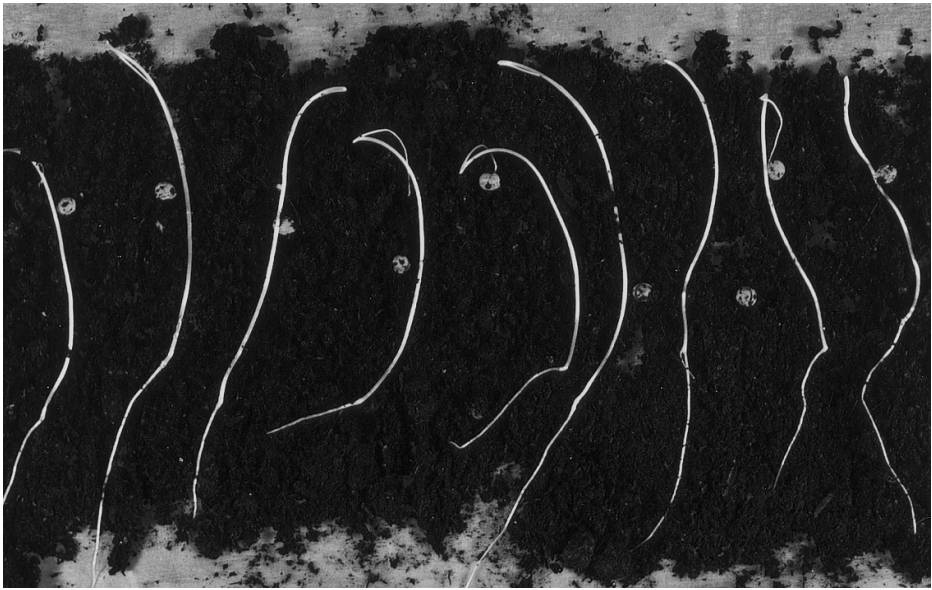

Fig. 8. Seedling growth of pelleted onion seeds in a roll towel germination test with peat.

less pesticide minimizes risks presented to the environment, including ground water contamination and the destruction of beneficial insects. In commercial applications, seed treatment technologies eliminate the use of additional equipment (tanks and pumps) and water needed for in-furrow drench applications. Furthermore, seed treatments limit worker exposure to pesticides in comparison with infurrow applications.

The registration of Trigard ${ }^{\circledR}$ was first pursued in the early 1990s. Concerns regarding registration of Trigard ${ }^{\circledR}$ as an in-furrow application focused on economics, because extensive testing is required for labeling a new plant protectant, including ground-water contamination studies. Furthermore, the cost of Trigard $^{\circledR}$ per hectare was greater than for the standard treatment with chlorpyrifos. These concerns resulted in a decreased incentive for pursuing Trigard ${ }^{\circledR}$ as an in-furrow application. Subsequently, a label was sought for Trigard ${ }^{\circledR}$ to be applied as a seed treatment. A Section 18 (emergency use label) was granted for Trigard ${ }^{\circledR}$ to be applied as a seed treatment from 1996 through 2000. The Section 18 label permits coating to occur in the State of California, while treated seeds could be sown in Michigan, Minnesota, New Jersey, New York, and Wisconsin. (California Environmental Protection Agency, 2000). The rationale for the label was that the major coating companies are located in California, so application can only be performed in that state, while seeds can only be sown in the onion production area that is affected by onion maggot in the northeastern and midwestern United States. PRO-GRO ${ }^{\circledR}$ is labeled in a similar manner, and can be applied in California and Washington and sown in selected states in the northeastern and midwestern United States (California Environmental Protection Agency, 2000). A Special Local Needs Registration (SLN \#970004) was granted for the same active ingredient to be applied as a seed treatment for export to Canada in 1997. Most recently, cyromazine has a Section 3 label in the United States (Novartis Crop Protection, 2000).

Cyromazine has the potential to affect germination and seedling growth. Phytotoxicity is pronounced during germination testing in which a relatively inert substrate is used as the germination medium (Fig. 7). The problem is not observed in the field in which onions are sown on high organic (muck) soils. The use of a "soil" is permitted in testing coated seeds if phytotoxic symptoms are evident (Association of Official Seed Analysts, 1993). A peat media placed over the seeds in a standard germination test adsorbs or detoxifies the plant protectants (Table 3). Therefore, seed testing can be performed for labeling of film-coated or pelleted seeds treated with plant protectants.

Collectively, film coating and pelleting were effective delivery systems for the application of insecticides and fungicides at the high loading rates required at time of sowing. Cyromazine was shown to be efficacious against onion maggot throughout this project and was compatible with the seed treatment fungicide PRO$\mathrm{GRO}^{\circledR}$. Cyromazine acts as an insect growth regulator by interrupting the life cycle of the onion maggot, and, due to its unique mode of action, has minimal impact on nondipterous insects. Thus, relative to standard insecticide treatments, cyromazine has negligible impact on the natural enemies of onion maggot, which is consistent with current IPM (Integrated Pest Management) strategies. Cyromazine applied as a seed treatment provides an alternative technology and chemistry (mode of action) to manage onion maggot compared to an in-furrow application of chlorpyrifos. Laboratory germination testing protocols with a peat media reduced potential phytotoxicity from the seed treatments, making it possible for the true quality of a seed lot to be assessed.

In retrospect, the success of this project was based on the creative inputs and efforts from university faculty programs, seed treatment specialists from Syngenta, and insightful onion growers. In fact, the initial idea of using a modern plant protectant (that eventually proved to be Trigard $^{\circledR}$ ) came from an onion grower. Although not highlighted in this paper, all field studies were conducted in grower fields where significant onion maggot infestations were known to exist, and the New York Onion Growers Association financially supported a large percentage of the applied research. This support was maintained from initial testing of materials through registration and beyond. Without the enthusiasm and assistance from the growers, this project would have never been initiated. Syngenta and other industry funds provided additional support. Large corporations are reluctant to register new plant protectants, especially on smallacreage crops. A team effort was essential for Syngenta to pursue research and development on a minor-use plant protectant. Moreover, regulatory personnel of the California Environmental Protection Agency were convinced during a site visit to New York onion fields of the importance of managing onion maggot with new materials and approaches. Future registrations on small acreage, high value horticultural crops are envisioned to require similar multi-partner approaches. Lastly, we recognize and thank university faculty programs from Michigan State Univ., East Lansing; Univ. of Wisconsin, Madison; and Univ. of Guelph, Ont., Canada for participating in collaborative studies with our seed coatings, thus providing a larger foundation of supporting field data from multiple locations.

\section{Literature Cited}

Association of Official Seed Analysts. 1992. Seedling evaluation handbook. Assn. Offic. Seed Analysts, Contrib. No. 35.

Association of Official Seed Analysts. 1993. Rules for testing seeds. J. Seed Technol. 16:1-113.

Butler, R. 1993. Coatings, films and treatments. Seed World. October, p. 18-24.

California Environmental Protection Agency. 2000. Dept. of Pesticide Regulation. Current Section 18 emergency exemptions. Cited from the World 
Wide Web 2 Apr. 2000. http://www. cdpr.ca.gov/docs/sec18/sect18s.htm.

Chapman, R.K. 1960. Status of insecticide resistance in insects attacking vegetable crops. Misc. Pub. Entomol. Soc. Amer. 2:27-39.

Davis, M., Y. Anandwala, M. Bommarito, and E. Grafius. 1995. Onion maggot control, 1994. Entomol. Soc. Amer., Arthropod Mgt. Tests 20:98-99.

Davis, M., E. Grafius, J. McDaniel, and P. Kolarik. 1994. Onion maggot control, 1993. Entomol. Soc. Amer. Arthropod Mgt. Tests. 19:102-103.

Duran, X. and J.S. Burris. 1997. Film coating impairs leaching of germination inhibitors in sugar beet seeds. Crop Sci. 37:515-520.

Eckenrode, C.J., N.L. Gauthier, D. Danielson, and D.R. Webb. 1973. Seedcorn maggot: Seed treatments and granule furrow applications for protecting beans and sweet corn. J. Econ. Entomol. 66:1191-1194.

Eckenrode, C.J., M.L. Hessney, D. Webb, and A.G. Taylor. 1999. Onion maggot control, 1998. Entomol. Soc. Amer., Arthropod Mgt. Tests 24:140.

Eckenrode, C.J. and J.P. Nyrop. 1995. Onion maggot management in New York, Michigan, and Wisconsin. N.Y. Food and Life Sci. Bul. 144.

Eckenrode, C.J., E.V. Vea, and K.W. Stone. 1975. Population trends of onion maggots correlated with air thermal unit accumulations. Environ. Entomol. 4:785-789.

Ellis, P.R. and C.J. Eckenrode. 1979. Factors influencing resistance in Allium sp. to onion maggot. Bul. Entomol. Soc. Amer. 25:151-153.

Ester, A. and R. de Vogel. 1994. Film-coating of leek seeds with insecticides: Effects on germination and on the control of onion fly [Delia antiqua (Meigen)], p. 195-199. In: T.J. Martin (ed.). Seed treatment: Progress and prospects.
Brit. Crop Protection Council Monogr. 57.

Ester, A., F. van de Steene, and S. Drieghe. 1997 Effects of filmcoating brussels sprouts seeds with various insecticides on the transport into the seedlings and on the control of cabbage root fly. J. Plant Dis. Protection 104:47-53.

Farm Chemicals Handbook. 2000. Meister Publ. Co., Willoughby, Ohio.

Grafius, E. and J. Hayden. 1988. Control of onion maggot, 1986. Entomol. Soc. Amer., Insect and Acaricide Tests. 13:126-127.

Gustafson, Inc. 2000. Labels and MSDSs. Cited from the World Wide Web, 12 Dec. 2000. http://www.gustafson.com/.

Gustafson, Inc. 2001. Gaucho and prescribe. Cited from the World Wide Web, 4 Jan. 2001. www.seedappliedinsecticide.com/.

Halmer, P. 1988. Technical and commercial aspects of seed pelleting and film coating, p. 191-204. In: T.J. Martin (ed.). Application to seeds and soil. Brit. Crop Protection Council Monogr. 39

Halmer, P. 2000. Commercial seed treatment technology, p. 257-286. In: M. Black and J.D. Bewley (eds.). Seed technology and its biological basis. Sheffield Acad. Press, Sheffield, U.K.

Hayden, J. and E. Grafius. 1990. Activity of cyromazine on onion maggot larvae (Diptera: Anthomyiidae) in the soil. J. Econ. Entomol. 83:2398-2400.

Hill, H.J. 1999. Recent developments in seed technology. J. New Seeds 1:105-112.

Howe, W.L., W.J. Schroeder, and K.G. Swenson. 1952. Seed treatment for control of seed-corn maggot and seed decay organisms. New York State Agr. Expt. Sta. Bul. 752.

Jeffs, K.A. and R.J. Tuppen. 1986. Application of pesticides to seeds. Requirements for efficient treatment of seeds, p. 17-45. In: K.A. Jeffs (ed.). Seed treatment. Brit. Crop Prot. Counc., Thornton
Heath, Surrey, U.K.

Kotze, A.C. and S.E. Reynolds. 1991. An examination of cuticle chitin and protein in cyromazineaffected Manduca sexta larvae. Pestic. Biochem. Physiol. 41:14-20.

Novartis Crop Protection. 2000. Labels and MSDSs. Section 3 specimen labels. Cited from the World Wide Web, 12 Dec. 2000. http://www.cp. us.novartis.com/.

Rawlins, W.A., M.J. Sloan, R.G. Strong, and J.J. Ellington. 1960. The onion maggot and its control. New York State Agr. Expt. Sta. Bul. 947.

Robani, H. 1994. Film-coating horticultural seed. HortTechnology 4:104-105.

Robbins, P.S., M.L. Hessney, and C.J. Eckenrode. 1991. Control of onion maggot, 1990. Entomol. Soc. Amer., Insect and Acaricide Tests 16:88.

Straub, R.W. and A.C. Davis. 1978. Onion maggot: Evaluation of insecticides for protection of onions in muck soils. J. Econ. Entomol. 71:684686.

Taylor, A.G. 1997. Seed storage, germination and quality, p. 1-36. In: H.C. Wien (ed.). The physiology of vegetable crops. CAB Intl., Wallingford, U.K.

Taylor, A.G., P.S. Allen, M.A. Bennett, K.J. Bradford, J.S. Burris, and M.K. Misra. 1998. Seed enhancements. Seed Sci. Res. 8:245-256.

Taylor, A.G., D.F. Grabe, and D.H. Paine. 1997. Moisture content and water activity of pelleted and film-coated seeds. Seed Technol. 19:24-32.

Webb, D.R., M.L. Hessney, and C.J. Eckenrode. 1996. Onion maggot control, Prattsburgh, 1995. Entomol. Soc. Amer. Arthropod Mgt. Tests 21:131.

Webb, D.R., A.G. Taylor, M.L. Hessney, and C.J. Eckenrode. 1992. Onion maggot control using pelleted Trigard seed treatments, 1991. Entomol. Soc. Amer., Insect and Acaricide Tests 17:120. 